Abstracta Iranica Abstracta Iranica

Revue bibliographique pour le domaine irano-aryen

Volume 24 | 2003

Comptes rendus des publications de 2001

\title{
«Seals on the Persepolis Fortification Tablets I: Images of Heroic Encounter », part 1: Text, part 2: Plates. OIP 117, 2001.
}

\section{Astrid Nunn}

\section{(2) OpenEdition}

Journals

Édition électronique

URL : http://journals.openedition.org/abstractairanica/34294

ISSN : 1961-960X

Éditeur :

CNRS (UMR 7528 Mondes iraniens et indiens), Éditions de l'IFRI

Édition imprimée

Date de publication : 15 mai 2003

ISSN : 0240-8910

Référence électronique

Astrid Nunn, « « Seals on the Persepolis Fortification Tablets I: Images of Heroic Encounter », part 1: Text, part 2: Plates. OIP 117, 2001. », Abstracta Iranica [En ligne], Volume 24 | 2003, document 61, mis en ligne le 05 janvier 2010, consulté le 25 septembre 2020. URL : http://journals.openedition.org/ abstractairanica/34294

Ce document a été généré automatiquement le 25 septembre 2020.

Tous droits réservés 


\title{
«Seals on the Persepolis Fortification Tablets I: Images of Heroic Encounter ", part 1: Text, part 2: Plates. OIP 117, 2001.
}

\author{
Astrid Nunn
}

1 Voilà enfin publié un travail attendu depuis des années! Ce volume (en deux parties) est le premier d'une série de trois sur la glyptique achéménide, tout particulièrement sur celle de Darius I ${ }^{\mathrm{er}}$. 1970 sceaux peuvent être reconstitués entièrement ou partiellement à partir de plusieurs milliers d'impressions sur les 2087 tablettes administratives élamites publiées par R. T. Hallock en 1969 (quantité totale estimée à 20 000-30 000). Ces tablettes datent des années 509-494 av. J.C. Dans ce premier volume sont présentés 312 sceaux. Un chapitre introductif nous renseigne sur les tablettes, les archives, sur les divers styles des sceaux et sur l'étude de leurs images. Tandis que le volume présent est consacré à l'image du héros, le second s'attachera à celle des activités humaines et le troisième volume aux animaux, aux plantes et aux motifs géométriques. Bien que l'objectif principal des auteurs soit (à juste titre) de faire connaître le matériel et non son analyse comparative, chaque sceau (reconstitué) est décrit, commenté et comparé à d'autres identiques ou semblables. Le motif du héros représente environ $27 \%$ du matériel des Persepolis Fortifications Tablets. Même si la signification générale du héros est évidente, celle dans son contexte internationalisé achéménide l'est bien moins. Les auteurs parlent d'une "figure générique symbolisant les forces collectives du pouvoir perse. Ce héros est une figure royale sans pourtant incorporer un roi précis, une entité flexible, à laquelle chaque personne d'identification perse pouvait s'associer » (p. 57). À mon avis, il n'est pas certain que ce héros d'antique origine mésopotamienne soit lié à l'idée royale. Je pencherais plutôt vers une idée abstraite de force liée à la protection, telle celle qui émane des nombreuses figures protectrices du genre laHmu. Cet opus n'est donc pas seulement une source pour 
l'iconographie achéménide, il servira aussi de référence au thème du héros dominant les animaux.

INDEX

Thèmes : 3.2.2. Pré-Achéménides et Achéménides

\section{AUTEURS}

ASTRID NUNN

Université de Munich 